\title{
Social Modification With The Changing Technology in The Case of Simplification Theory
}

\author{
Rana Nur Ülker ${ }^{1}$, Büșra Turhan ${ }^{1}$
}

\begin{abstract}
Mc. Luhan's told "The world become global village" came truth. The global village, which main tools are mass media technologies, especially internet, made civilization socials. With the rise of the global communication, every new inventions can be known easily and the technology can be observed. As Marcuse said that the global communication not only makes people same but also simple. Tools are being simple which is understood by everybody from every civilization indeed every age period. In this study, we try to debate this matter, why and how "simplification theory" can make people and technology simple. The simplification theory can be defined as when the media technologies are changed, peoples values and overlook of world are modified. Due to fact that societies' value and argument about the world translated technologic devices. To sum up, all the instrument of the about human being has changed.
\end{abstract}

Key words: Simplification, Social Modification, Mass Media, Technology, Globalization

\section{Introduction}

All of the inventions that mankind has brought to life have influenced both man and nature. Every innovation has caused to forget previous and it has become impossible to think without this innovation. Human, who communicated through voices, began to draw on the walls and did not feel that to live without these pictures. The need to voices for human did not block drawing ability on the walls unlike both abilities is developed together. We witnessed all around the world that human nature changed with the invention of writing. We can see that people, who kept in mind those accounts at first time, can able to deal it without a fight with their minds after the invention of writing. Sumerians Writing, introduced by the Sumerians into human history, has paved the way to the formation of today's global world with its invention. Discovery of writing, within the time zone, provided to spread quickly inventions, ideas, and news. Our principal is beside the point "with the invention of writing people who give up memorization". The characterization of peoples whose mind shaped by rote is different the people whose characterization shaped by pictures. Spread of writing and the uses of daily life cause the replace of memorization. If we look at the history, we can clearly say that after "Hafiz" who memorized the Qur'an, the holy book of the Muslims, was on reduction in the number because of dying in the war, St. Osman ordered to be record of the Qur'an in writing. This situation emerges in reverse as a reading.

While Ong is talking about Homer problem in his essay, named Orality and Literacy,The Technologizing of the World, he refers to Milman Parry's doctoral dissertation that says 
even we investigate works about oral culture, we are doing these views by the brain structure, created by written culture. After pushing aside these prejudices, we can see that verbal bards' repertoire is very wide. It is large enough that, for the narrative dimensions required by each string could easily add adjectives (1991:35). The memory, memorizing 600-page Holy Book, Qur'an, and memory, which tells the Iliad and Odyssey, was taking power from the same base memory.

Basalla, refers modern commentators' argument and he describes the invention as "mother of requirements"(2002:18). Basalla says in a study about inventions;

"The car's inventor was not referring to details of the business requirements. In other words, a serious automobile at the international scale attack or as a result of shortages at implemented. National leaders, thinkers, and check out the newspaper columnists, replaced by a new calling on people to find transportation were not found. Inventers' motor transport is a serious societal and individual need and there were not citizens who could solve this problem expectantly for very soon. In fact, the first ten years of existence in the world of automobile throughout (1895-1905), people who can buy himself by a toy or a recreational vehicle was considered." (2002:19).

From here, we can say that people with inventions, while facilitating their daily lives, reducing workload and the number, and the reduction of time allocated to work, they finally have practiced for fun and the proliferation of leisure time.

Turning points in history, technological discoveries often appear in front of us. People were trespassing from residual groups to hunting and they become farmers, engaged in agriculture; as a result, that process brought new tools while the daily use, population growth, rising standard of living, residential units. Daily business can make people easier, less tired. The change of transportation patterns changed the size of trade, education, interpersonal communication, and organized social life again, so much so that people' foods, clothes and information are influenced by this development. Looking at the history of the world, we can say that historically, human life, civilizations and cultural accumulation, has been formed as a result of technological discoveries. (Carr, 2012:67)

\section{From Globalization to Simplification}

In the 1960s, Marshall McLuhan argued that the world would convert to electronic global village, globalization, by evaluating the developments of communication technology. If the term globalization is defined as concentration of social relation or increased awareness of being a whole format, we can see that the beginning of this term insists to the earlier periods. (Scholte,2008:107)

The important feature of global mass culture is Western-centric. West technology has become the router power of global mass culture with monopoly capital increase and advanced techniques. Globalization refers interaction between people in different countries and increase of this mutual interaction

Today, via message delivery system from non-remote locations has been used by the political authority of the Roman Empire firstly and then it has been used by the political, religious and commercial elites in medieval Europe. At the end of the fifteenth century with the development of the printing press books, and other printed materials were distributed far beyond where they are produced. Moreover, with trade relations with other regions of the world economy progresses in Europe, the area of Europe and other regions of the world which were being drawn increased by European colonial expansion were established communication channels. 
According to George Ritzer, the global culture brings three separate topic of discussion. Differentialism is hybridity and cultural conflict. It is highlighted that cultural conflict causes to be prototype in a specific way of globalization. Accordingly, in recent years, it has been argued that several areas of lifestyles and worldwide has caused to be a single format. (Ritzer,2011:276) The smallest change of this prototype, created by the individuals, affects many bilateral relations area from the family to the economy, social life, work life, sense of fun. (Kağıtç̧ıaşı, 1988: 275)

Globalization has led that people and capital can move in a way that is comfortable and free and the use of English as the common language in the media has provided relaxed and easy way of its globalization. (Ilgaz,2004:50) Multinational companies in the world market can leverage to further grow and develop, and similar consumption patterns for the masses would like to create. Thus, the world is becoming a uniform homogenous market. According to Bauman Zygmunt, the basic element of this new order is globalized. This multinational company significantly is seen as the process of globalization players. Today we are witness to technological advances, and also as confirming both Carr and Basalla's argument, inventions, make people's lives easier. This convenience allows us to do our jobs quickly, while we will heighten time for fun. (Öztürk,2013:240) While people are doing activities such as entertainment, transportation and business, besides making quickly of them, they want this sleight without complex. Human being, fleeing complexity, is undergoing to a non-key re-live from the challenging world of confusing and key. The instrument used is made simple, and tools, which handle our business with simple movements, are pushing people simplification.

\section{Simplification Theory}

Today, individuals are intensively besieged by computer, television and video communication. Since the 1970s the technology boom has affected the community and the economies as unexpected levels. In the process, developments in information technology, defined as the 'information revolution ', were quick to make the computerdependent society (Kocacik,2003:3).

Due to fact that computer language is easy to detect format, the topics of conversation have increased in computer environments. In this way, the computers have begun to be used in wide areas, for instance, entertainment, education, home, business, and professional work. Ken Hirschkop refers to that revolution in technology provides to connect the speed of new information types with a great opportunity. Hirschkop argue that fax machine, cable TV and the Internet are the most popular tools of the revolution, and these technological tools and computer technology thanks to recent developments with a fairly large distributed virtual realm throughout the world the data so that it can become possible interaction between people who use the computer(McChesney,2003: 243).

The simplification theory can be defined as when the media technologies are changed, people's values and overlook of world are modificated. Due to fact those societies' value and argument about the world translated technologic devices. To sum up, all the instruments of the about human being have changed. 
According to Baudrillard, at postmodern times, in the contrast of modern times, the innovations are based on, modern times innovations, humans are not creative, and they are reproducing.

In 1990's, there was a belief, which argued that the developing technology the robots would take place of human. Now, we can say, the robots does not replace with human self but humans are become a robots, which needs to electricity for living. In other words, when we look for the people, we can find them near the sockets.

When we think, we try to answer the question why people become addicted to the technology?

First, the thing which makes us the excellent range is that Google is to be with us throughout our life. Google has taught us the search culture, but it has also prevented to use our memory for long time. We can be informed by means of search engine search without holding just a thought and without the need to the library.

The log usage of these vehicles has been driven by the change of brain cells and over time while it has weakened the old nerve paths, it has reinforced new nerve paths. (Small, 2008: 1) Google embodies our reasoning ability and it destroys our ability to keep in memory. Therefore, it renders us an individual who cannot think of any information.

Thanks to our smart phones, we can participate in all the activities that we want, can call and can be socializing with one-touch. While technological tools make our lives easy, becoming a simple form, and 1-year old children, have no literature, can use visual symbols in all operation same as adults. At the same time, we can say that users who are adults can do same operations with1-year-old kids who do not have any literature.

Individuals cannot escape from this cycle and, in the words of Walter Ong, people, researching oral culture, were doing these jobs with their brains which are shaped by written culture. Thanks to information age, we have become to think with our brain which is influenced by the technological developments, in fact our discourse it makes us simplify.

\section{In Lieu of a Conclusion}

As a result, today's human is a generation, who is acculturated with the Cyber generation, media and computer culture, is separated pieces by information and media technologies, are playing computer games, can reach to the channel they want to on TV, can connect to the internet, can create original identification forms in his social relationships and grows with post-modern culture. Thanks to Internet, multimedia, computer technologies and information circulation, displays and cultural forms, are dramatically changing. As a result, modern human learn to live with changing forms of culture, high-tech information society and multimedia.

Modern human, having privileged features of the post modernization, is the first generation, which is experiencing with cyber space, surreal reading and vignettes that change. All kinds of technology emerged and developed such as media culture, computers, genetic engineers, change all facets of our lives. 


\section{References}

BASALLA,G., The Evolution of Technology, 2002, Cambridge University Press

CARR, N., The Shallows: What the Internet is Doing to Our Brains?, 2010, W.W. Norton, New York

ILGAZ,C., B, Türkiye'de Televizyon Alanında Küresel Yerel Birlikteliği, 2004, İstanbul Üniversitesi İletişim Fakültesi Yayınları, İstanbul

KAĞITÇIBAŞI,Ç., İnsan ve İnsanlar, 1988, Evrim Yayınları,İstanbul

KOCACIK,F., Bilgi Toplumu ve Türkiye,2003, C.Ü. Sosyal Bilimler Dergisi, Vol.27, No:11

MCCHESNEY,R., W., Capitalism and the Information Age, 1998, Epos Yayınlar1, Ankara

ONG, W., Orality and Literacy, The Technologizing of the Word,1991, Methis Publishing

ÖZTÜRK,G. R., Digital Reklamcılık ve Gençlik, 2013, Beta Yayınları, İstanbul

RITZER, G., Globalization: A Basic Text,2009, Wiley-Blackwell

SCHOLTE,J., A., Globalization 2000, Mac.Millian Academic

SMALL, G. and GigiVORGAN, iBrain: Surviving the Technological Alteration of the Modern Mind, New York: Collins 
